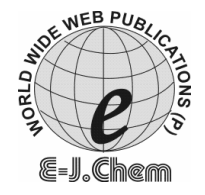

http://www.e-journals.net
ISSN: 0973-4945; CODEN ECJHAO

E-Journal of Chemistry 2009, 6(3), 866-870

\title{
Antimicrobial Evaluation and Synthesis of Some Phenylpyrazolo benzothiazolo quinoxaline Derivatives
}

\author{
CH. SRIDEVI ${ }^{*}$, K. BALAJI, A. NAIDU and R.SUDHAKARAN \\ *Department of Pharmaceutical Chemistry, \\ Geethanjali College of Pharmacy, \\ Cheeryal(V), Keesara(M), Hyderabad.501301, India. \\ sridevi.phd@gmail.com
}

Received 25 November 2008; Accepted 16 January 2009

\begin{abstract}
Diphenyl quinoxaline (SI) was fused with 2-amino benzothiazoles (SII) by a methylene bridge, which was then allowed for acetylation. The acetylated product (SIV) was made to react with different aromatic aldehydes to give chalcones (SV1-SV5). Chalcones refluxed with substituted acid hydrazides to afford different phenyl pyrazolo benzothiazolo quinoxaline derivatives (SVI1SVI15). The structure of chalcones and phenyl pyrazolo benzothiazolo quinoxaline derivatives were confirmed by M.P, TLC and spectral data. All the synthesized compounds were screened for their antimicrobial activities.
\end{abstract}

Keywords: 2,3-Diphenyl quinoxaline, 2-Amino benzothiazole, Phenyl pyrazolo benzothiazolo quinoxaline, Antimicrobial activity.

\section{Introduction}

Pharmacologically, phenyl pyrazolo benzothiazolo quinoxaline derivatives are known to exhibit important biological activities like antimicrobial ${ }^{1}$ antitubercular ${ }^{2}$, anti-inflammatory ${ }^{3}$, antioxidant $^{4}$, antihistamic ${ }^{5}$, antidepressant ${ }^{6}$, hypoglycemic, hypotensive, anticarcenogenic activities ${ }^{7}$ etc. In view of these reports the synthesis of title compounds has been undertaken in the present note (Scheme 1) and their anti microbial properties are reported. In view of the above facts, it was contemplated to design and synthesize some phenyl pyrazolo benzothiazolo quinoxaline derivatives by condensing benzothiazolo quinoxaline chalcones with different aromatic acid hydrazides. All the synthesized compounds were screened for their anti microbial activities. The structure of chalcones and phenyl pyrazolo benzothiazolo quinoxaline derivatives were confirmed by M.P, TLC, and spectral data. 


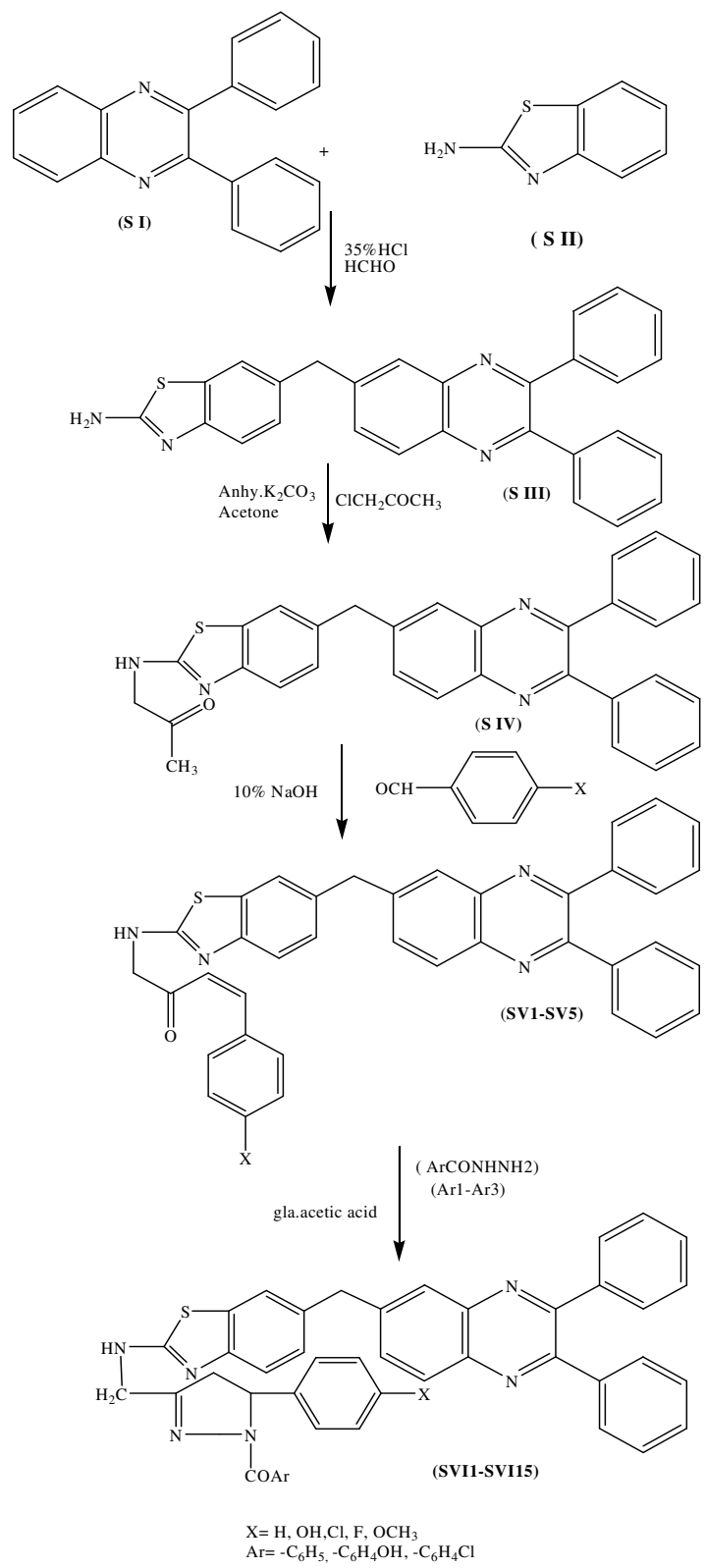

\section{Experimental}

\section{Scheme 1}

The melting point of the compounds was determined on a Thoshniwal electric melting point apparatus and the values were uncorrected. I.R spectra of the compounds were recorded on a Thermo Nicolet Nexus 670-FTIR, IICT, Hyderabad using KBr disc method. ${ }^{1} \mathrm{H}$ NMR spectra were recorded on Avance-300, IICT, Hyderabad using $\mathrm{CDCl}_{3}$ as solvent. Mass spectra were recorded on HITACHI RMU GL, IICT, Hyderabad. All the solvents used were of analytical grade. 
General procedure for synthesis of 6-((2,3-diphenylquinoxalin-6yl) methyl)benzo [d] thiazol-2-amine(SIII) ${ }^{8}$

2,3 Diphenyl quinoxaline (SI) and 2-aminobenzothiazole (SII) were prepared using following literature method. SI and SII are linked with a methelyne bridge by treating equimolar quantities of SI and SII in a suitable solvent with 35 parts formaldehyde solution and $35 \% \mathrm{HCl}$, stirred for $4 \mathrm{~h}$. at $70{ }^{\circ} \mathrm{C}$ using magnetic stirrer. Solution was made alkaline using ammonia solution. The product was filtered and recrystallized with aqueous ethanol.

General procedure for synthesis of 1-(6-((2,3-diphenylquinoxalin-6-yl) methyl) benzo[d]thiazol-2 -yl amino) propan-2-one (SIV) ${ }^{9}$

A solution of SIII $(0.01 \mathrm{M})$ and chloroacetone $(0.01 \mathrm{M})$ were taken into $250 \mathrm{~mL}$ round bottom flask. Added to it $150 \mathrm{~mL}$ of dry acetone and $30 \mathrm{~g}$ of anhydrous potassium carbonate and the reaction mixture were refluxed for $6 \mathrm{~h}$ below $75{ }^{\circ} \mathrm{C}$. Filterate obtained was concentrated under vaccum and recrystallized with aqueous ethanol.

General procedure for (Z)-1-(6-((2,3-diphenylquinoxalin-6-yl) methyl) benzo[d] thiazol-2-yl amino)-4-phenylbut-3-en-2-one (SV1-SV5) ${ }^{10}$

A solution of $\mathrm{NaOH} / \mathrm{KOH}(8 \mathrm{~mL}, 10 \%$ in water) was added drop wise to a well stirred solution of SIV $(0.01 \mathrm{M})$ and $(0.01 \mathrm{M})$ of appropriate aldehyde in $20 \mathrm{~mL}$ ethanol. The reaction mixture was stirred for $24 \mathrm{~h}$ at cold conditions. Then diluted with ice water and acidified with con. $\mathrm{HCl}$. Filtered the product and recrystallized with aqueous ethanol. The purity of the compound was checked by TLC and melting point.

General procedure for synthesis of (3-(6-((2,3diphenylquinoxalin-6yl) methyl) benzo[d]thiazol-2-yl amino) methyl)-4,5-dihydro-5-phenylpyrazol-1- yl)(phenyl) methanone (SVI1-SVI15) ${ }^{11}$

Chalcone $(0.01 \mathrm{M})$ and aromatic acid hydrazide $(0.02 \mathrm{M})$ were taken in $20 \mathrm{~mL}$ glacial acetic acid and refluxed for $10 \mathrm{~h}$ above $130{ }^{\circ} \mathrm{C}$. The reaction mixture was concentrated and poured in $300 \mathrm{~mL}$ of ice cold water and recrystallized with aqueous ethanol. The purity of the compound was checked by TLC and melting point. Physical data are shown in Table 1.

\section{Antimicrobial evaluation}

Antifungal activity ${ }^{12}$

All the compounds were evaluated in vitro for antifungal activity by using cup plate method by different strains of fungi like Aspergillus fumigates, Candida albicans, Candida glabrata and Candida krusei. All the compounds along with standard fluconezole were used at a concentration of $250 \mathrm{mg} / \mathrm{mL}$. 10\% DMSO in methanol was used as solvent control and sabour and dextrose agar was used as culture medium. Compounds SVI-13, SVI-14, SVI-15 exhibited highest degree of antifungal activity and compounds SVI-3, SVI-4, SV-5, SVI-8, SVI-9, SVI-10 showed moderate antifungal activity (Table 2).

\section{Antibacterial activity ${ }^{13}$}

This study was assayed by employing the cup plate method by measuring inhibition zones in $\mathrm{mm}$. All the tested compounds along with standard ciprofloxacin was screened in vitro for antibacterial activity against gram positive Staphylococcus aureus and Bacillus subtilis, gram negative Pseudomonas aeruginosa and Escherichia coli. The sterile nutrient agar medium was melted and inoculated with 16-18 hours old broth culture at $1 \%$ level. The inoculation has to be completed under aseptic conditions and when the medium was in molten state. 
The inoculated medium was transferred to sterile Petri dishes, evenly distributed and allowed to solidify. Thereafter the cups $(8 \mathrm{~mm}$ diameter) were made by punching into the agar surface with a sterile cork borer and scooping out the punched part of the agar. Into each of these cups, $0.05 \mathrm{~mL}(50 \mu \mathrm{g})$ of the test compound/reference standard was added using a micropipette. The plates were incubated at $37^{\circ} \mathrm{C}$ for $16 \mathrm{~h}$ and the zone of inhibition was measured. The data indicated that compounds SVI-5, SVI-10, SVI-15 showed excellent activity against E.coli and Bacillus subtilis. SVI-14, SVI-15 showed excellent activity against Staphylococcus aureus. SVI-14, SVI-15 showed has shown little activity against Pseudomonas aeruginosa Table 3.

Table 1. Physical data of phenyl pyrazolo benzothiazolo quinoxaline derivatives.

\begin{tabular}{llllccc}
\hline Compd. & \multicolumn{1}{c}{$\mathrm{X}$} & \multicolumn{1}{c}{$\mathrm{Ar}$} & \multicolumn{1}{c}{$\begin{array}{c}\text { Molecular } \\
\text { Formula }\end{array}$} & $\begin{array}{c}\text { Melting point } \\
\text { range }\end{array}{ }^{\circ} \mathrm{C}$ & \% Yield & $\mathrm{R}_{\mathrm{f}}$ value \\
\hline SVI1 & $\mathrm{H}$ & $\mathrm{C}_{6} \mathrm{H}_{5}$ & $\mathrm{C}_{45} \mathrm{H}_{34} \mathrm{~N}_{6} \mathrm{OS}$ & $120-122$ & 70 & 0.89 \\
SVI2 & $\mathrm{OH}$ & $\mathrm{C}_{6} \mathrm{H}_{5}$ & $\mathrm{C}_{45} \mathrm{H}_{34} \mathrm{~N}_{6} \mathrm{O}_{2} \mathrm{~S}$ & $115-116$ & 67 & 0.8 \\
SVI3 & $\mathrm{F}$ & $\mathrm{C}_{6} \mathrm{H}_{5}$ & $\mathrm{C}_{45} \mathrm{H}_{33} \mathrm{FN}_{6} \mathrm{OS}$ & $114-116$ & 66 & 0.87 \\
SVI4 & $\mathrm{Cl}$ & $\mathrm{C}_{6} \mathrm{H}_{5}$ & $\mathrm{C}_{45} \mathrm{H}_{33} \mathrm{ClN}_{6} \mathrm{OS}$ & $112-113$ & 78 & 0.9 \\
SVI5 & $\mathrm{OCH} \mathrm{H}_{3}$ & $\mathrm{C}_{6} \mathrm{H}_{5}$ & $\mathrm{C}_{46} \mathrm{H}_{36} \mathrm{~N}_{6} \mathrm{O}_{2} \mathrm{~S}$ & $114-116$ & 67 & 0.86 \\
SVI6 & $\mathrm{H}$ & $\mathrm{OHC}_{6} \mathrm{H}_{4}$ & $\mathrm{C}_{45} \mathrm{H}_{34} \mathrm{~N}_{6} \mathrm{O}_{2} \mathrm{~S}$ & $120-124$ & 66 & 0.91 \\
SVI7 & $\mathrm{OH}$ & $\mathrm{OHC}_{6} \mathrm{H}_{4}$ & $\mathrm{C}_{45} \mathrm{H}_{34} \mathrm{~N}_{6} \mathrm{O}_{3} \mathrm{~S}$ & $119-120$ & 80 & 0.93 \\
SVI8 & $\mathrm{F}$ & $\mathrm{OHC}_{6} \mathrm{H}_{4}$ & $\mathrm{C}_{45} \mathrm{H}_{33} \mathrm{FN}_{6} \mathrm{O}_{2} \mathrm{~S}$ & $108-110$ & 45 & 0.9 \\
SVI9 & $\mathrm{Cl}$ & $\mathrm{OHC}_{6} \mathrm{H}_{4}$ & $\mathrm{C}_{45} \mathrm{H}_{33} \mathrm{ClN}_{6} \mathrm{O}_{2} \mathrm{~S}$ & $112-115$ & 45 & 0.8 \\
SVI10 & $\mathrm{OCH}$ & $\mathrm{OHC}_{6} \mathrm{H}_{4}$ & $\mathrm{C}_{45} \mathrm{H}_{36} \mathrm{~N}_{6} \mathrm{O}_{3} \mathrm{~S}$ & $110-112$ & 67 & 0.89 \\
SVI11 & $\mathrm{H}$ & $\mathrm{ClC}_{6} \mathrm{H}_{4}$ & $\mathrm{C}_{45} \mathrm{H}_{33} \mathrm{ClN}_{6} \mathrm{OS}$ & $110-112$ & 56 & 0.88 \\
SVI12 & $\mathrm{OH}$ & $\mathrm{ClC}_{6} \mathrm{H}_{4}$ & $\mathrm{C}_{45} \mathrm{H}_{33} \mathrm{ClN}_{6} \mathrm{O}_{2} \mathrm{~S}$ & $120-122$ & 78 & 0.82 \\
SVI13 & $\mathrm{F}$ & $\mathrm{ClC}_{6} \mathrm{H}_{4}$ & $\mathrm{C}_{45} \mathrm{H}_{32} \mathrm{ClFN}_{6} \mathrm{OS}$ & $130-131$ & 76 & 0.79 \\
SVI14 & $\mathrm{Cl}$ & $\mathrm{ClC}_{6} \mathrm{H}_{4}$ & $\mathrm{C}_{45} \mathrm{H}_{32} \mathrm{Cl}_{2} \mathrm{~N}_{6} \mathrm{OS}$ & $120-124$ & 56 & 0.98 \\
SVI15 & $\mathrm{OCH}$ & $\mathrm{ClC}_{6} \mathrm{H}_{4}$ & $\mathrm{C}_{46} \mathrm{H}_{35} \mathrm{ClN}_{6} \mathrm{O}_{2} \mathrm{~S}$ & $123-126$ & 54 & 0.8 \\
\hline
\end{tabular}

Table 2. Antifungal activity of phenyl pyrazolo benzothiazolo quinoxaline derivatives.

\begin{tabular}{ccccc}
\hline Compound & $\begin{array}{c}\text { Antifungal activity, diameter of the inhibition zone, mm } \\
\text { Aspergillus } \\
\text { fumigates }\end{array}$ & $\begin{array}{c}\text { Candida } \\
\text { albicans }\end{array}$ & $\begin{array}{c}\text { Candida } \\
\text { krusei }\end{array}$ & $\begin{array}{c}\text { Candida } \\
\text { glabrata }\end{array}$ \\
\cline { 2 - 5 } Control & 0 & 0 & 0 & 0 \\
Fluconezole & 10 & 29 & 19 & 15 \\
SVI1 & - & - & - & - \\
SVI2 & - & - & - & - \\
SVI3 & 7 & 17 & 14 & 9 \\
SVI4 & 7 & 16 & 12 & 9 \\
SVI5 & 6 & 15 & 13 & 9 \\
SVI6 & - & - & - & - \\
SVI7 & - & - & - & - \\
SVI8 & 6 & 15 & 10 & 9 \\
SVI9 & 5 & 17 & 11 & 10 \\
SVI10 & 7 & 15 & 12 & 9 \\
SVI11 & 5 & 20 & 9 & 8 \\
SVI12 & 7 & 20 & 12 & 8 \\
SVI13 & 10 & 22 & 17 & 14 \\
SVI14 & 9 & 22 & 18 & 15 \\
SVI15 & 9 & 28 & 18 & 14 \\
\hline
\end{tabular}


Table 3. Antibacterial activity of phenyl pyrazolo benzothiazolo quinoxaline derivatives.

\begin{tabular}{ccccc}
\hline Compound & $\begin{array}{c}\text { Antibacterial activity, diameter of the inhibition zone, mm } \\
\text { Staphylococcus } \\
\text { aureus }\end{array}$ & $\begin{array}{c}\text { Bacillus } \\
\text { Subtilis }\end{array}$ & E.coli & $\begin{array}{c}\text { Psedomonas } \\
\text { aeruginosa }\end{array}$ \\
\cline { 1 - 3 } \cline { 5 - 5 } Control & 0 & 0 & 0 & 0 \\
ciprofloxacin & 20 & 21 & 20 & 19 \\
SVI1 & - & - & - & - \\
SVI2 & 10 & 10 & 11 & 9 \\
SVI3 & 15 & 15 & 15 & 10 \\
SVI4 & 12 & 15 & 15 & 10 \\
SVI5 & 15 & 19 & 19 & - \\
SVI6 & 10 & 12 & - & - \\
SVI7 & 11 & 13 & 14 & 9 \\
SVI8 & 14 & 16 & 18 & - \\
SVI9 & 14 & 19 & 18 & - \\
SVI10 & 16 & 20 & 19 & 11 \\
SVI11 & 10 & 13 & 12 & 8 \\
SVI12 & 12 & 13 & 14 & 9 \\
SVI13 & 16 & 11 & 11 & 13 \\
SVI14 & 19 & 13 & 13 & 14 \\
SVI15 & 20 & 21 & 20 & 14 \\
\hline
\end{tabular}

\section{Conclusions}

Synthesis of some phenyl pyrazolo benzothiazolo quinoxaline derivatives by condensing benzothiazolo quinoxaline chalcones with different aromatic acid hydrazides have been done successfully. All the synthesized compounds were screened for their anti microbial activities. Compounds SVI-13, SVI-14, SVI-15 exhibited highest degree of antifungal activity and compounds SVI-3, SVI-4, SV-5, SVI-8, SVI-9, SVI-10 showed moderate antifungal activity and the compounds SVI-5, SVI-10, SVI-15 showed excellent activity against E.Coli and Bacillus subtilis. SVI-14, SVI-15 showed excellent activity against Staphylococcus aureus. SVI-14, SVI-15 showed has shown little activity against Pseudomonas aeruginosa.

\section{Acknowledgements}

The authors are thankful to IICT Hyderabad, spectral analysis. Also thankful to Geethanjali College of Pharmacy for providing facilities to carry out research work.

\section{References}

1. Paget C J, Patent U S, 3, 974, 286, 10 Aug 1976, Chem Abstract., 1977, 86, 5468.

2. $\quad$ Pandy, Anil V \& Lokhande S R, Indian drugs, 1982, 19, 9.

3. Mehre S C and Zaman S J, Indian Chem Soc., 1980, 57, 829.

4. Sandeep Kotharkar and Devender B Shinda, Bioorg Med Chem Lett., 2006, 16, 6181.

5. Dubey PK, Naidu A, Vijaya S and George B, Vineel, Indian J Chem., 2005, 44B, 573.

6. Ganapathy S, Ramalingam P and Baburao Ch, Indian J Hetero Chem., 2007, 16, 283.

7. Kumar A, Sharma S, Bajaj K. Indian J Chem., 2003, 42B(8),1979.

8. Suthakaran R, Nagarajan G, Balasubramaniam V, Suganthi K and Velrajan G, Indian J Heterocycl Chem., 2005, 14, 201.

9. Leonard J T, Yagnapriya S, Sridhar S K and Gunasekaran V, Indian J Heterocycl Chem., 2005, 14, 377.

10. Suthakaran.R, Somasekhar G, Sridevi Ch, Mari kannan M, Suganthi K and Nagarajan G, Asian J Chem., 2007, 5, 3353.

11. Harinadha babu V, Sridevi Ch, Joseph A and Srinivasan KK, Indian J Pharm Sci., 2007, 66(8), 470.

12. Sharma T C, Bokadia M M and Reddy N J, Indian J Chem, 1980, 19B, 228.

13. Fathema.M, Bharmal, Devender and Hansa, Indian J Heterocycl Chem., 2000, 12, 189. 


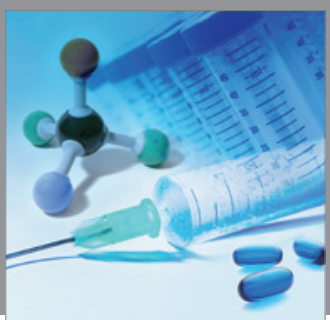

International Journal of

Medicinal Chemistry

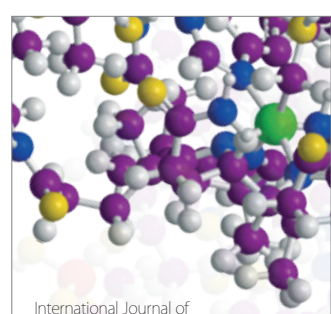

Carbohydrate Chemistry

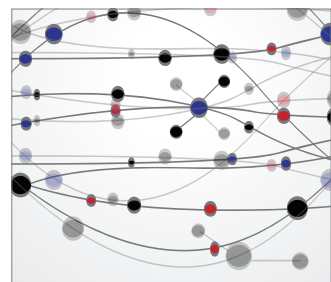

The Scientific World Journal
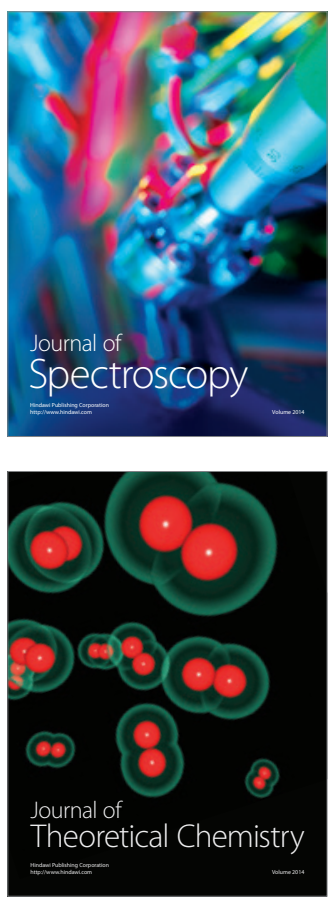
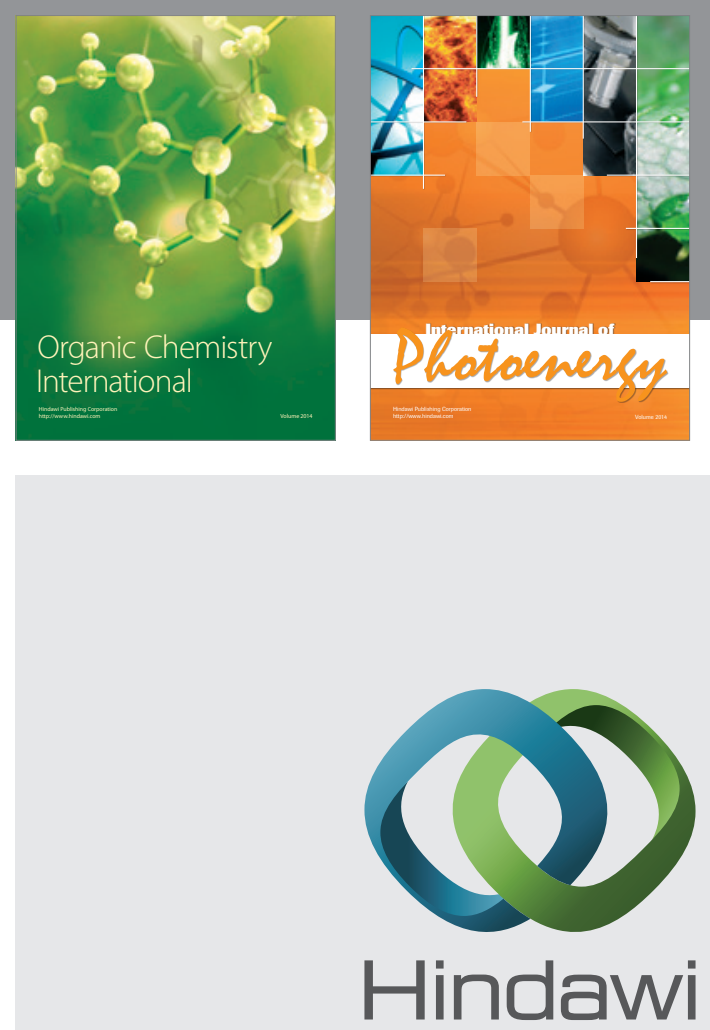

Submit your manuscripts at

http://www.hindawi.com
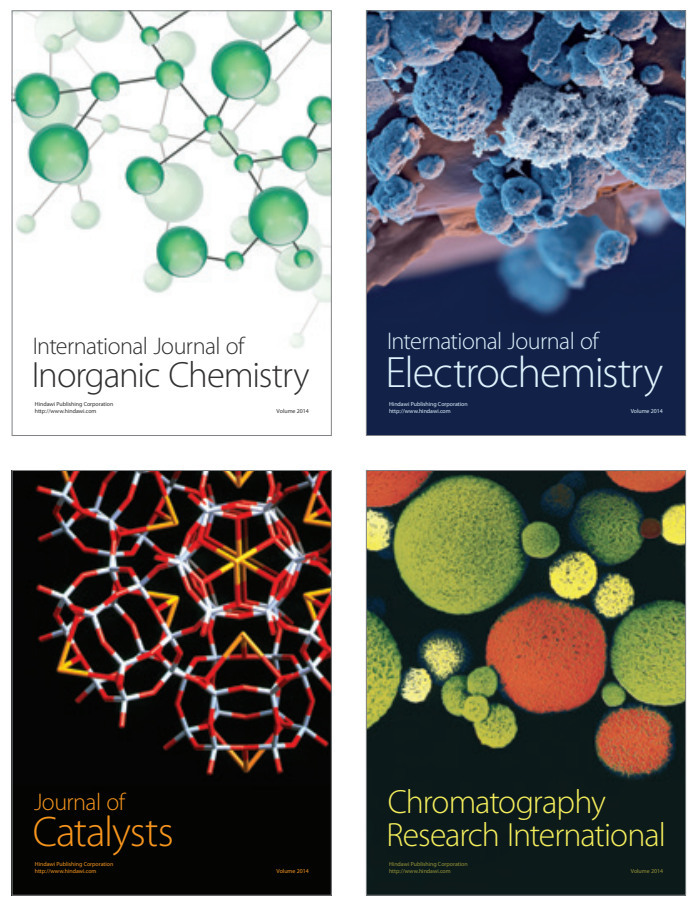
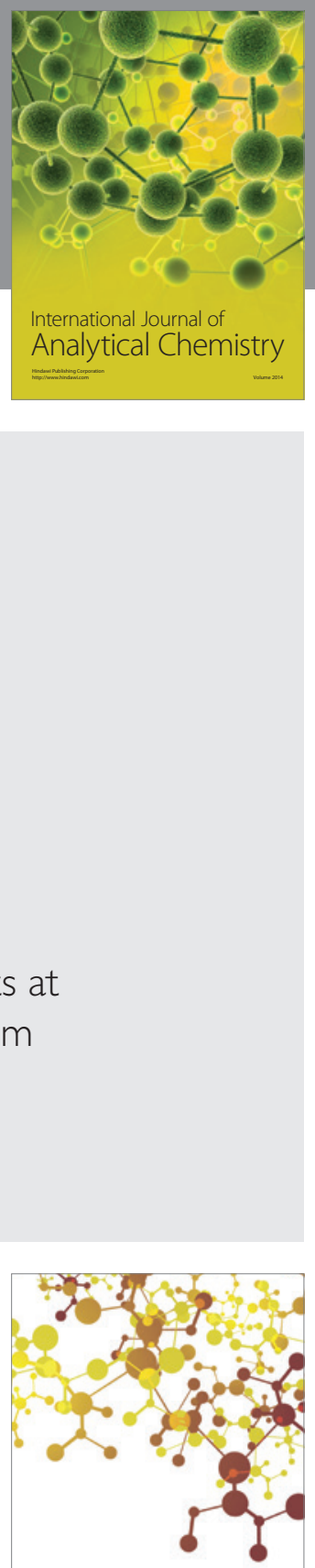

Journal of

Applied Chemistry
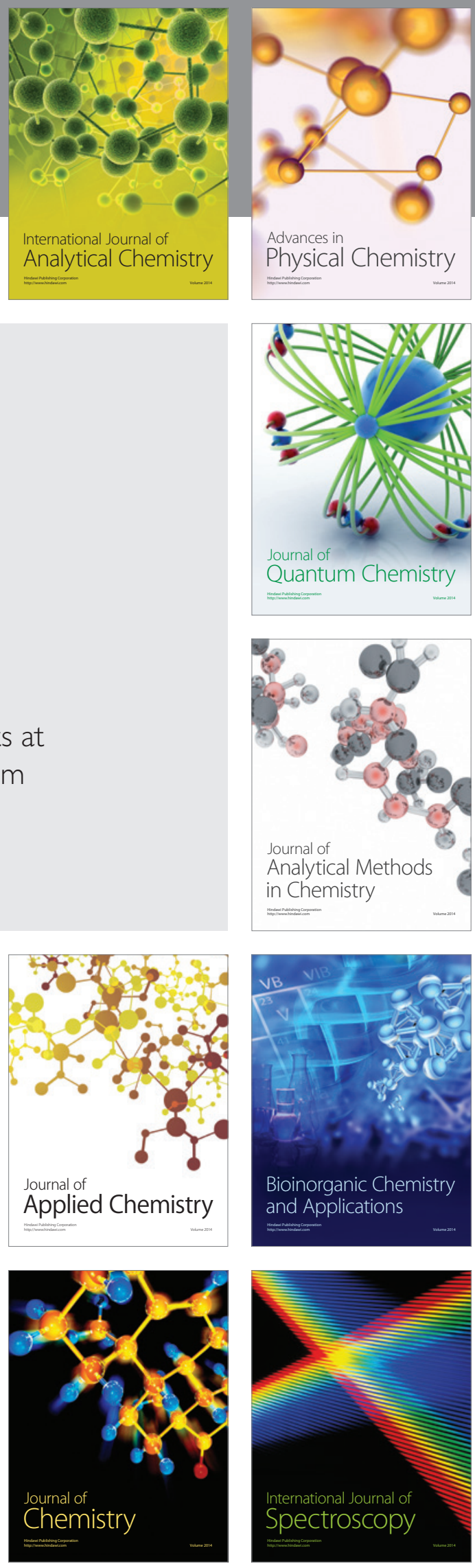